"The use of traditional marketing tools by SMEs in an emerging economy: a South African perspective"

\begin{tabular}{ll} 
AUTHORS & $\begin{array}{l}\text { Michael C. Cant } \\
\text { Johannes A. Wiid }\end{array}$ \\
\hline ARTICLE INFO & $\begin{array}{l}\text { Michael C. Cant and Johannes A. Wiid (2016). The use of traditional marketing } \\
\text { tools by SMEs in an emerging economy: a South African perspective. Problems } \\
\text { and Perspectives in Management, 14(1), 64-70. doi:10.21511/ppm.14(1).2016.07 }\end{array}$ \\
\hline DOI & http://dx.doi.org/10.21511/ppm.14(1).2016.07 \\
\hline RELEASED ON & Wednesday, 02 March 2016 \\
\hline JOURNAL & "Problems and Perspectives in Management" \\
\hline FOUNDER & LLC “Consulting Publishing Company "Business Perspectives"
\end{tabular}

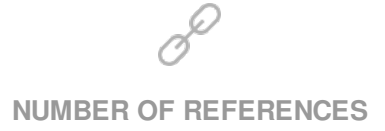

0

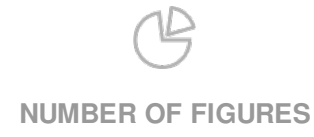

0

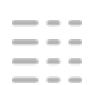

NUMBER OF TABLES

0

(C) The author(s) 2022. This publication is an open access article. 
Michael C. Cant (South Africa), Johannes A. Wiid (South Africa)

\title{
The use of traditional marketing tools by SMEs in an emerging economy: a South African perspective
}

\begin{abstract}
Small and medium enterprises (SMEs) play a vital role in all economies around the world, they are responsible for creating of jobs, alleviating of poverty, contributing to innovation and to the gross domestic product of a country. However, many of these businesses face challenges and often fail within a short period of time. The success of small businesses is not only having products and a market to sell them to but also effective marketing of these products to the targeted market. A vast array of studies have investigated SME marketing tool usage however few have looked to SMEs in emerging economies and specifically to the traditional marketing tools such firms employ. Therefore the focus of this study was to describe the usage of traditional marketing tools employed by SMEs from a South African perspective. This study followed a quantitative research methodology whereby a self-administered questionnaire was distributed to SME owners within the Gauteng province of South Africa. Results obtained from this research indicate that SME owners mostly make use of print media while broadcast media is used selectively. Results obtained within this study will be of value universally to SME owners as it can be seen that all SMEs irrespective of geographic location face similar challenges.
\end{abstract}

Keywords: marketing, traditional marketing tools, SMEs, South Africa, emerging economy. JEL Classification: M10.

\section{Introduction}

Despite the growth of internet usage and online marketing in recent years (Internet World Stats, 2014; Sledzik, 2014) it appears that many small and medium enterprises (SMEs) are still opting to utilize traditional marketing tools (OuterBrand, 2015; Sledzik, 2014). According to Sledzik (2014) a study conducted by Brandmuscle found that SMEs are of the opinion that online marketing is complicated and time consuming making them more hesitant to invest in these more modern techniques. However, while some SMEs are struggling to adopt new online marketing tools, many argue that their current traditional marketing tool usage is working and therefore they do not feel the need to explore new options (OuterBrand, 2015). This paper aims to investigate the extent to which South African SMEs utilize traditional marketing tools in their marketing actions.

\section{Literature review}

1.1. Traditional marketing. Marketing plays an important part in any organization large or small, as without it producers and consumers would not be able to find one another (Salehi, Mirzaei, Aghaei \& Abyari, 2012, p. 385), more specifically, through marketing, businesses achieve success by determining and satisfying the aspirations, needs and wants of their targeted consumers (Walsh \& Lipinski, 2009, p. 569). The American Marketing

(C) Michael C. Cant, Johannes A. Wiid, 2015.

Michael C. Cant, D.Com. in Business Management with specialization in Marketing and Retail Management, Professor, Department of Marketing and Retail Management, University of South Africa, South Africa.

Johannes A. Wiid, D.Com. in Business Management with specialization in Marketing and Retail Management, Professor, Department of Marketing and Retail Management, University of South Africa, South Africa.
Association (2014) defines marketing as "...the activity, set of institutions, and processes for creating, communicating, delivering, and exchanging offerings that have value for customers, clients, partners, and society at large." Traditional marketing tools can be described according to Taherdoost and Jalalivoon (2014) as business cards, magazines, newspapers, posters, commercials on television as well as brochures and billboard. In essence traditional marketing includes all promotional efforts except digital marketing tools. Traditional marketing tools fall under four categories, namely (Marketing-schools.org, 2012; \& Seriously simple marketing, 2015):

- Print media: Examples of which include newspapers, brochures, magazines and newsletters that are distributed to potential consumers.

- Broadcast media: Such as radio, television and on-screen theatre advertising.

- Direct mail: This includes postcards, brochures and catalogues that are printed and sent to potential or current consumers of the product.

- Telemarketing: Calling consumers directly to find out if they would like to purchase the company's product.

While new forms of marketing communication are emerging in the 21 st century such as e-marketing, many businesses still make use of traditional marketing tools to promote their merchandize, and especially small businesses, due to their limited marketing budgets (Marketing-schools.org, 2012).

1.2. SMEs and its contribution to the South African economy. There is no generally accepted definition of an SME. Although it can be described 
as an independent organization that employs less than a given number of employees, the definition of an SME by size however varies among researchers (Abor \& Quartey, 2010, p. 219); for the purpose of this research SMEs will be considered to have between 1-150 employees.

SMEs play a significant role in the economies of many countries throughout the world (Olawale \& Garwe, 2010, p. 729). They are often described as "efficient and prolific job creators, the seeds of big businesses and the fuel of national economic engines" (Abor \& Quartey, 2010, p. 218). SMEs account for about $91 \%$ of formal businesses in South Africa, contributing between 51-57\% of the country's gross domestic product (GDP) and providing approximately $60 \%$ of employment (Kongolo, 2010, p. 2288; Abor \& Quartey, 2010, p. 219). Due to their potential for job creation, innovation, stimulation of economic expansion and the alleviation of poverty in developing countries (Kongolo, 2010, p. 2288; Dlodlo \& Dhurup, 2010, p. 164), governments worldwide have focused on small business development in order to promote economic growth (Olawale \& Garwe, 2010, p. 729).

Despite the evidence that SMEs play a vital role in the economy and their notable contributions, it appears that South African SMEs have some of the highest failure rates in the world with approximately $75 \%$ of new SMEs not blooming into established organizations (Olawale \& Garwe, 2010, p. 730). According to Van Scheers (2011, p. 5048), 40\% of new SMEs fail within their first year, $60 \%$ within their second year, and $90 \%$ within their first 10 years of operation. Such high failure rates may be due to a number of factors including management skills, finance, access to markets and appropriate technology (Kongolo, 2010, p. 2293) and as mentioned previously, this may further influence SMEs in their decision to invest in online marketing or remain in the sphere of traditional marketing.

1.3. SME usage of traditional marketing tools. Marketing is vital for the growth of any business, as without it a business could offer the best products on the market but nobody would know of its existence (Hawes in: fin24, 2013). Ralph Waldo Emerson often cited for saying "Build a better mousetrap and the world will beat a path to your door", is a fallacy in marketing as having a good product is only one aspect in getting your product in the hands of consumers (Critchfield, 2010). In response to this theory Emerson O.B. Winters responds to say that even if you have a good mousetrap (product) you need to show this mousetrap to the world in order to fully succeed (Pritchett, 2011). While the importance of the marketing concept applies to all organizations, it is well documented within literature that large organizations' marketing efforts differ substantially from that of SMEs (Gilmore, Carson \& Grant, 2001, p. 6; \& Reijonen, 2010, p. 279).

SME marketing efforts are hindered by various aspects such as the size of the business, lack of marketing knowledge, poor cash flow or small budget and tactical and strategic customer-related problems (O'Dwyer, Gilmore \& Carson, 2009, p. 46). However, despite various hindrances SMEs face in implemented marketing activities, the business activity remains essential to the success of the business. It therefore becomes important that the marketing activities that contribute strongly to a SMEs performance be identified (Walsh \& Lipinski, 2009, p. 570).

According to BusinessNewsDaily (2013) traditional marketing tools still thrive, with $77 \%$ of SMEs still using print advertising. Traditional marketing tools appear to have spoken more to consumers and to attracting the consumer to purchase the offering (Salehi, 2012, p. 385). Sledzik (2014) found the following statistics on SME marketing strategies:

- SMEs consider that the most tried and true marketing tactics are the most effective. SMEs seem to be most satisfied with the following marketing tools: local events, coupons, billboards and email.

- The most frequently used marketing tools are coupons $(83 \%)$, direct mail/postcards (81\%), local events (79\%), email (72\%) and websites (72\%).

- The least frequently used marketing tools are daily deals (such as Groupon) (29\%), magazines $(45 \%)$, billboards $(45 \%)$, nontraditional advertising (such as vehicle advertising) (47\%) and television (50\%).

Although traditional marketing tools work for some, many marketers believe that this strategy is ineffective. For example, in a survey regarding businesses opinions on lead quality and quantity by channel, only $4 \%$ of respondents indicated that leads generated from print, radio and TV ads were high quality and only 9\% indicated that this channel delivered a high quantity of leads (Ross, 2013). 


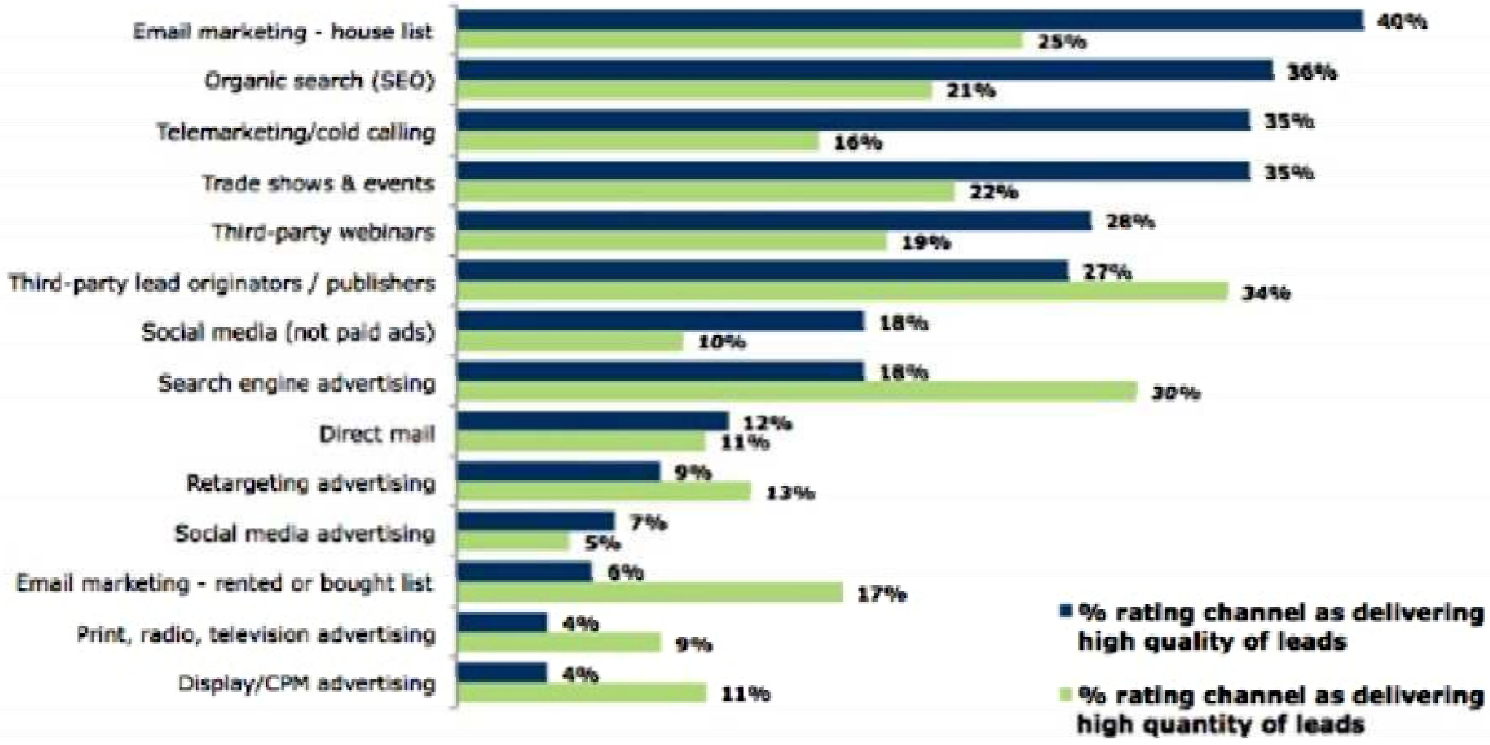

Fig. 1. Businesses opinions on lead quality and quantity by channel

Sledzik (2014) further states that traditional marketing tools leave many dissatisfied, with a number of SMEs least satisfied with advertising in magazines, newspapers and the yellow page listings. In addition, traditional marketing tools are expensive which in turn affects SMEs in their decision to invest in television and radio advertising, billboards, newspapers and yellow pages listings.

\section{Aim and methodology}

The purpose of this research study was to describe the usage of traditional marketing tools employed by Small Medium Enterprises (SMEs) in the emerging economy of South Africa.

The way in which data were collected for this study was through the distribution of a self-administered questionnaire to SME owners that reside within the Gauteng province of South Africa and whose businesses (SMEs) are registered at an official state institution. A non-probability, convenience sampling methodology was employed by the researchers as it allowed for quick and easy collection of data. The questionnaire was composed of questions that were quantitative in nature which therefore allowed business owners to indicate their usage of traditional marketing tools. An acceptable number of questionnaires were distributed to obtain a confidence level of $95 \%$ and an error margin of $10 \%$ at $50 \%$ response distribution was achieved. 71 useful responses were received which contains an error margin of $11.38 \%$.

The low number of responses only give a general indication of the usage and effectiveness of traditional marketing tools in South African SMEs and the findings cannot be inferred to all SMEs, further research is needed.
The data obtained were checked, coded and corrected, where after it was analyzed using the software program IBM SPSS Statistics V22. Descriptive statistics in the form of frequency counts was used to describe the findings. Descriptive statistics were used to describe which traditional marketing tools had previously been used, how often and how effective the SME owners found the particular traditional marketing tool to be.

\section{Findings}

Findings obtained in this study take into consideration the respondents' composition in terms of employee numbers, frequency of marketing plan updates and the monthly amount that SME owners spend on traditional marketing tools.

3.1. Respondent composition. From Table 1 below it can be observed that from the 71 responses received, 67 SME owners provided information on the amount of employees they have in their business. Of the 67 responses received $55(82.1 \%)$ indicated that they have less than 20 employees. The number of employees was non-normally distributed, with a skewness of $3.42(\mathrm{SE}=0.293)$ and kurtosis of 12.06 ( $\mathrm{SE}=0.578)$. Most of the 68 businesses that provided information on their monthly expenses on marketing activities $(51.5 \%)$ indicated that they spent less than R1000 per month, while $38.2 \%$ spent between R1001 and R5000. The monthly expenses on marketing activities were non-normally distributed, with skewness of $1.202(\mathrm{SE}=0.291)$ and kurtosis of $-1.330(\mathrm{SE}=0.574)$. Of the businesses that provided information on the frequency of updating of their marketing plan (66 respondents), $50 \%$ indicated that they update their marketing plan once a year while $27.3 \%$ update the plan once a month. Frequency of the updating of the 
marketing plan was normally distributed, with skewness of $-0.261(\mathrm{SE}=0.295)$ and kurtosis of $-0.253(\mathrm{SE}=0.582)$.

Table 1. Number of employees

\begin{tabular}{|l|c|c|}
\hline Number of employees & Count(n) & $\%$ \\
\hline Less than 20 & 55 & 82.1 \\
\hline $21-40$ & 7 & 10.4 \\
\hline $41-60$ & 1 & 1.5 \\
\hline $61-80$ & 2 & 3.0 \\
\hline More than 100 & 2 & 3.0 \\
\hline Total & 67 & 100.0 \\
\hline Monthly marketing expenses \\
\hline Less than R1 000 & 35 & 51.5 \\
\hline R1 001-R5 000 & 26 & 38.2 \\
\hline R5 001-R10 000 & 5 & 7.4 \\
\hline More than R10 000 & 2 & 2.9 \\
\hline Total & 68 & 100.0 \\
\hline Frequency of updating marketing plan \\
\hline Once a week & 3 & 4.5 \\
\hline
\end{tabular}

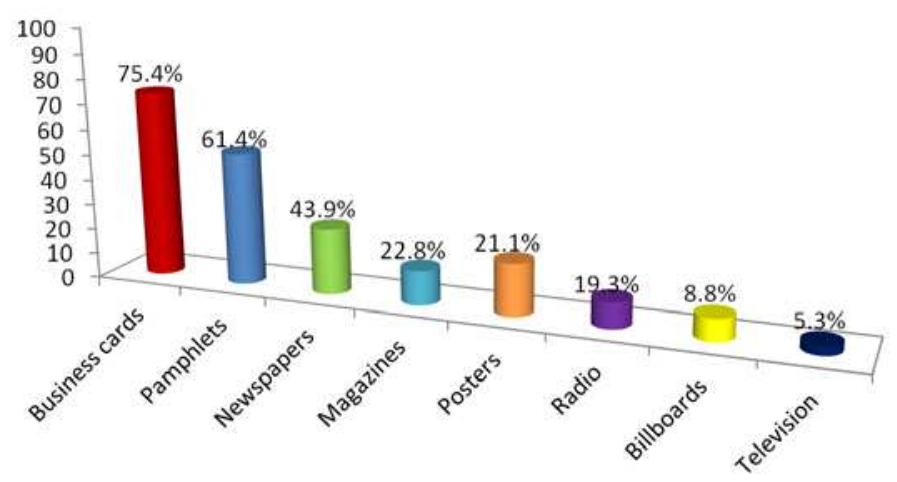

Fig. 2. Percentage of respondents having used traditional marketing tools

Once past usage had been determined, SME owners were asked to indicate the frequency for which they use stated traditional marketing tools.

\subsection{Frequency of traditional marketing tool usage.}

\begin{tabular}{|l|c|c|}
\hline Once a month & 18 & 27.3 \\
\hline Once a year & 33 & 50.0 \\
\hline Once every 5 years & 12 & 18.2 \\
\hline Total & 66 & 100.0 \\
\hline
\end{tabular}

Respondents were next asked about their usage of traditional marketing tools in the past. The following section shall now discuss the results obtained.

\subsection{Past usage of traditional marketing tools.}

Traditional marketing tools were used by more than $20 \%$ of the total responses received, the top five tools used were: business cards $(75.4 \%)$, pamphlets (61.4\%), newspapers (43.9\%), magazines $(22.8 \%)$ and posters $(21.1 \%)$. Almost a fifth $(19.3 \%)$ of the respondents reported to have used radio for marketing purposes in the past. The two least used traditional marketing tools according to responses were billboards and television - used by only $8.8 \%$ and $5.3 \%$ of respondents respectively (see Figure 2 below).

Table 2. Descriptive statistics for the question on the frequency of use

\begin{tabular}{|c|c|c|c|c|c|c|c|c|c|c|}
\hline \multirow{2}{*}{$\begin{array}{c}\text { Traditional } \\
\text { marketing tools }\end{array}$} & \multicolumn{2}{|c|}{$\mathrm{N}$} & \multirow{2}{*}{ Mean } & \multirow{2}{*}{ Median } & \multirow{2}{*}{ Mode } & \multirow{2}{*}{ Std. deviation } & \multirow{2}{*}{ Skewness } & \multirow{2}{*}{$\begin{array}{l}\text { Std. error of } \\
\text { skewness }\end{array}$} & \multirow{2}{*}{ Kurtosis } & \multirow{2}{*}{ Std. error of Kurtosis } \\
\hline & Valid & Missing & & & & & & & & \\
\hline Pamphlets & 63 & 8 & 3.05 & 4.00 & 4 & 1.549 & -.270 & .302 & -1.516 & .595 \\
\hline Business cards & 69 & 2 & 4.03 & 5.00 & 5 & 1.424 & -1.310 & 289 & .323 & .570 \\
\hline Radio & 58 & 13 & 1.69 & 1.00 & 1 & 1.188 & 1.611 & .314 & 1.492 & .618 \\
\hline Television & 55 & 16 & 1.22 & 1.00 & 1 & .738 & 3.936 & .322 & 16.102 & .634 \\
\hline Billboards & 57 & 14 & 1.44 & 1.00 & 1 & 1.053 & 2.358 & .316 & 4.456 & .623 \\
\hline Poster & 58 & 13 & 2.16 & 1.00 & 1 & 1.374 & .719 & .314 & -.902 & .618 \\
\hline Magazines & 59 & 12 & 1.78 & 1.00 & 1 & 1.260 & 1.342 & .311 & .450 & .613 \\
\hline Newspapers & 58 & 13 & 2.24 & 1.00 & 1 & 1.455 & .625 & .314 & -1.165 & .618 \\
\hline
\end{tabular}

a. Multiple modes exist. The smallest value is shown.

Due to the exploratory nature of the study descriptive statistics were used to analyze the data. Responses were grouped into three ratings on the Likert scale due to the sample size, the two lowest frequency scales were grouped into one "Not at all \& rarely" and the two highest frequency scales "Often \& always".
From the descriptive statistics obtained for the question pertaining to the frequency of use of the different traditional marketing tools, it is evident that the frequencies are non-normally distributed (see Table 2 below): 


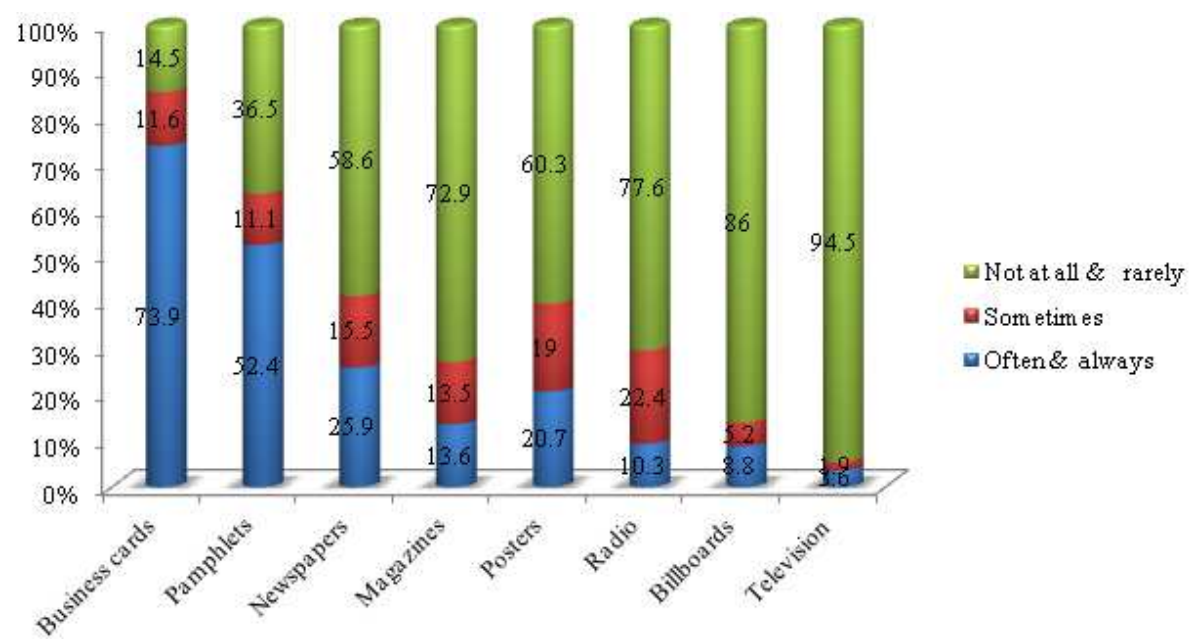

Fig. 3. Frequency analysis of the frequency of using traditional marketing tools

Treating the variable as continuous, and keeping in mind that higher values correspond with higher levels of agreement with a statement, one can see from the means that the two most frequently used traditional marketing tools are business cards $($ Mean $=4.0)$ and pamphlets $($ Mean $=3.0)($ see Figure 4 below $)$.

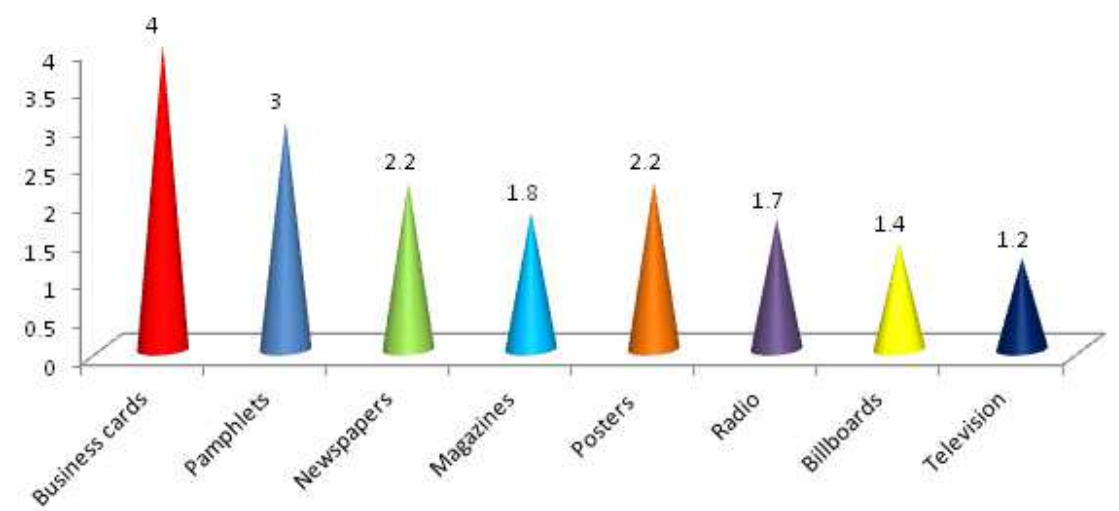

Fig. 4. Mean values of the ratings of the frequency of using traditional marketing tools

3.4. The effectiveness of the use of traditional marketing tools. From the descriptive statistics for the questions on the effectiveness of use of the different traditional marketing tools, it is clear that the frequencies are non-normally distributed (Table 3).

Table 3. Descriptive statistics for the questions on the effectiveness of use of marketing tools

\begin{tabular}{|c|c|c|c|c|c|c|c|c|c|c|}
\hline \multirow{2}{*}{ Traditional marketing tools } & \multicolumn{2}{|r|}{$\mathrm{N}$} & \multirow{2}{*}{ Mean } & \multirow{2}{*}{ Median } & \multirow{2}{*}{ Mode } & \multirow{2}{*}{ Std. deviation } & \multirow{2}{*}{ Skewness } & \multirow{2}{*}{ Std. error of Skewness } & \multirow{2}{*}{ Kurtosis } & \multirow{2}{*}{ Std. error of Kurtosis } \\
\hline & Valid & Missing & & & & & & & & \\
\hline Pamphlets & 63 & 8 & 3.57 & 4.00 & 5 & 1.411 & -.577 & .302 & -.954 & .595 \\
\hline Business cards & 65 & 6 & 4.12 & 4.00 & 5 & 1.023 & -.886 & .297 & -.033 & .586 \\
\hline Radio & 59 & 12 & 3.49 & 4.00 & 5 & 1.490 & -.647 & .311 & -.940 & .613 \\
\hline Television & 54 & 17 & 3.35 & 4.00 & 5 & 1.662 & -.435 & .325 & -1.462 & .639 \\
\hline Billboards & 53 & 18 & 3.28 & 4.00 & 5 & 1.598 & -.396 & .327 & -1.405 & .644 \\
\hline Poster & 54 & 17 & 3.59 & 4.00 & 5 & 1.381 & -.602 & .325 & -.758 & .639 \\
\hline Magazines & 49 & 22 & 3.29 & 3.00 & $3^{\mathrm{a}}$ & 1.500 & -.359 & .340 & -1.171 & .668 \\
\hline Newspapers & 55 & 16 & 3.47 & 4.00 & 5 & 1.438 & -.544 & .322 & -.975 & .634 \\
\hline
\end{tabular}

a. Multiple modes exist. The smallest value is shown

All of the traditional marketing tools are rated as either "Effective or very effective" by most of the respondents (more than 50\%), except magazines (44.9\%). The top three tools rated in terms of efficiency "Effective or very effective" are business cards $(70.8 \%)$, radios $(57.6 \%)$ and pamphlets (57.1\%) (see Figure 5 below). The bottom four rated traditional media tools as posters and television $(53.7 \%)$, billboards $(52.8 \%)$ and magazines $(44.9 \%)$. 


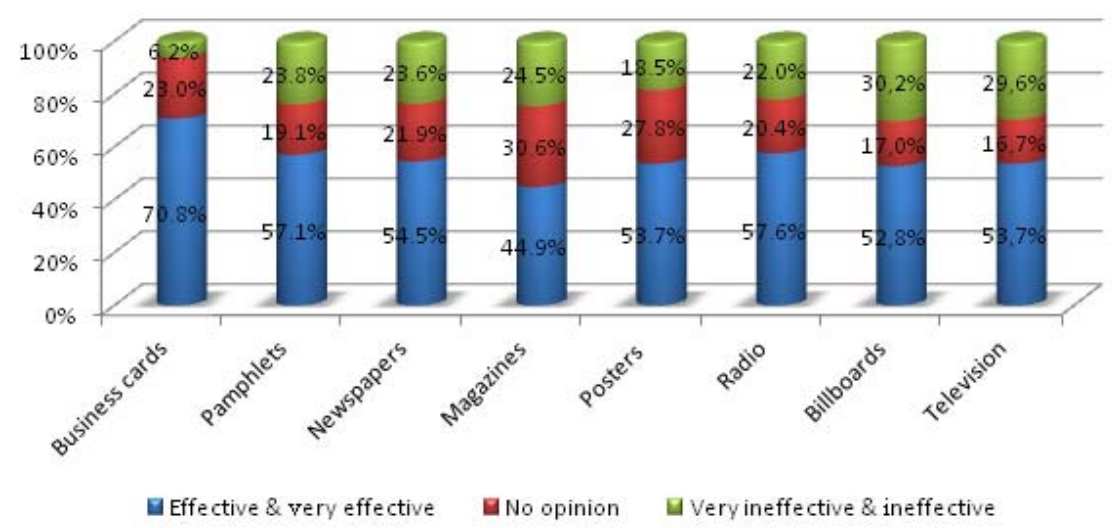

Fig. 5. Frequency analysis of the effectiveness of using traditional marketing tools

Treating the variable as continuous, and keeping in mind that higher values correspond with higher ratings of effectiveness, one can see that the three most effective marketing tools are perceived as business cards (mean $=4.1$ ), pamphlets
$($ mean $=3.6)$ and posters $($ mean $=3.6)$ (see Figure 6 below). This is followed by the rest of the traditional marketing tools rated with an average above 3 , which is the middle value of the scale (from 1 to 5 ).

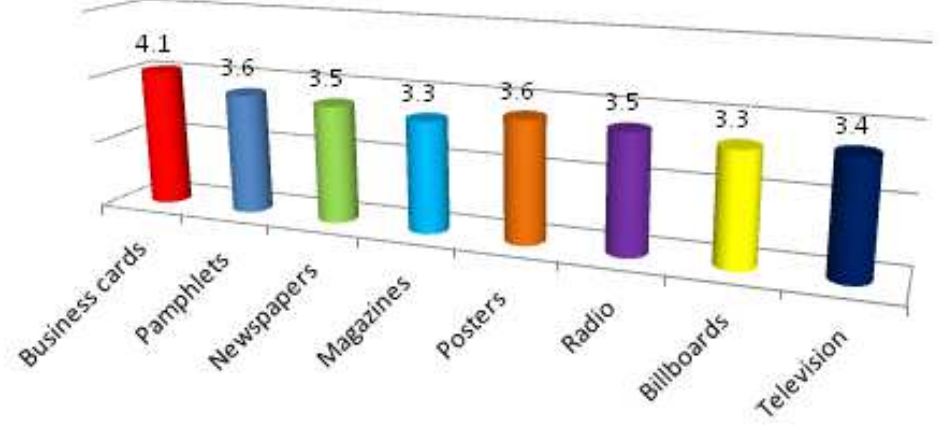

Fig. 6. Mean values of the effectiveness ratings of using traditional marketing tools

The following section shall now discuss the conclusions and recommendations that emanate from the findings discussed above.

\section{Conclusion and recommendations}

Traditional marketing tools can be described as any none digital means of communicating with one's target audience and can be seen to fall in four categories namely print, broadcast, direct and telemarketing (Marketing-schools.org, 2012; \& Seriously simple marketing, 2015). While online marketing has become a recent trend and has whirled its way into the marketing plans of larger organizations, many SMEs are still comfortable with and maintain the use of traditional marketing tools. The purpose of this research study was to describe the usage of traditional marketing tools employed by SMEs in the emerging economy of South Africa. The study revealed that, more than half of the respondents had businesses that comprised of less than 20 employees, spent less than R1000 monthly on their marketing activities and only updated their marketing plan once a year. The main traditional marketing tools employed by respondents in the past were that of business cards and pamphlets.
While broadcast media such as radio and television were not used to a great extent in the past by respondents, all of the traditional marketing tools are however rated as "Effective \& Very Effective" by the majority of respondents. The top five traditional marketing tools according to respondents were: business cards, pamphlets, posters, newspapers and the radio, while magazines, billboards and television were seen to be slightly less effective. (These results correlate with the literature, whereby, due to the expense of traditional marketing tools SMEs may be reluctant to invest in television and radio advertising, billboards and newspapers).

While a number of marketers believe that the use of traditional marketing is ineffective, it is recommended that SME owners incorporate online marketing to complement their traditional marketing activities. As discussed in the literature, previous research has found that events, coupons, billboards and email appears to be the most effective tools. It is therefore suggested that South African SMEs use such tools to their advantage. Online marketing and social media marketing can be used as complementary, rather than a 
replacement to traditional marketing tools, it is therefore recommended that SMEs be trained in the use of both traditional and online marketing tools so as extend the life of the SME. It is further recommended that future research be conducted into the area of SME traditional marketing tool usage to determine activities and competencies that contribute most strongly to business performance in terms of turnover and to establish best practice for SME businesses and to avoid unnecessary capital wastage on endeavours that do not work. One limitation that must be noted is that the findings obtained within this research cannot be generalizable due to the sample size therefore it is recommended that further research be conducted with a larger sample size to determine the most effective traditional marketing tools employed by SMEs.

\section{References}

1. Abor, J. \& Quartey, P. (2010). Issues in SME Development in Ghana and South Africa, International Research Journal of Finance and Economics, 39, pp. 218-228.

2. American marketing association. (2014). Definition of marketing. Available at: https://archive.ama.org/Archive/ AboutAMA/Pages/DefinitionofMarketing.aspx. Accessed: 2014-04-08.

3. BusinessNewsDaily. (2013). Social marketing takes hold, but traditional marketing still thrives. Available at: http://www.businessnewsdaily.com/972-social-marketinging-small-business.html. Accessed: 2015-08-28.

4. Critchfield, B. (2010). Marketing means building a better mousetrap. Available at: http://forbesindia.com/article/ thunderbird/marketing-means-building-a-better-mousetrap/11392/1. Accessed: 2015-09-07.

5. Dlodlo, N. \& Dhurup, M. (2010). Barriers to e-marketing adoption among small and medium enterprises (SMEs) in the Vaal Triangle. Available at: http://www.google.co.za/url?sa=t\&rct=j\&q=\&esrc=s\&frm=1\&source=web\&cd=2\&ved $=0 \mathrm{CCYQFjAB} \& u r l=\mathrm{http} \% 3 \mathrm{~A} \% 2 \mathrm{~F} \% 2 \mathrm{Fwww} \cdot$ actacommercii.co.za\%2Findex.php $\% 2 \mathrm{Facta} \% 2 \mathrm{Farticle} \% 2 \mathrm{Fdownload} \% 2$ F126\%2F126\&ei=zKkVVM2DIKO7Qbw8oCYBg\&usg=AFQjCNGeYfHTAMPCIXJxhnCkIfvJonew-g. Accessed: 2014-04-07.

6. Gilmore, A., Carson, D \& Grant, K. (2001). SME marketing in practice, Journal or marketing intelligence \& planning, 19 (1), pp. 6-11. Available at: http://dx.doi.org/10.1108/02634500110363583. Accessed: 2015-08-28.

7. Hawes, J. In: fin24. (2013). Marketing essential for SME growth. Available at: http://www.fin24.com/Entrepreneurs/ Getting-Started/Marketing-essential-for-growth-of-an-SME-20130723. Accessed: 2014-04-09.

8. Internet World Stats. (2014). Internet growth statistics. Available at: http://www.internetworld stats.com/emarketing.htm. Accessed: 2014-04-07.

9. Kongolo, M. (2010). Job creation versus job shedding and the role of SMEs in economic development, African Journal of Business Management, 4 (11), pp. 2288-2295.

10. Marketing-schools.org. (2012). Traditional marketing. Available at: http://www.marketing-schools.org/types-ofmarketing/traditional-marketing.html. Accessed: 2015-08-28.

11. O’Dwyer, M., Gilmore, A. \& Carson, D. (2009). Innovative marketing in SMEs, European Journal of Marketing, 43 (1/2). Available at: http://dx.doi.org/10.1108/03090560910923238. Accessed: 2015-08-28.

12. Olawale, F. \& Garwe, D. (2010). Obstacles to the growth of new SMEs in South Africa: A principal component analysis approach, African Journal of Business Management, 4 (5), pp. 729-738.

13. OuterBrand. (2015). Traditional vs modern marketing tools. Available at: http://www.outerbrand.com/blog/ 2015/07/08/traditional-vs-modern-marketing-tools/. Accessed: 2015-08-28.

14. Pritchett, G. (2011). The great mousetrap fallacy. Available at: http://www.thebusinesslaunchpad.com/the-greatmousetrap-fallacy/. Accessed: 2015-08-28.

15. Reijonen, H. (2010). Do all SMEs practice same kind of marketing? Journal of Small Business and Enterprise development, 17 (2), pp. 279-293. Available at: http://dx.doi.org/10.1108/14626001011041274. Accessed: 2015-08-28.

16. Ross. (2013). Small business marketing guide: Types of traditional and online marketing. Available at: http://blog.crowdspring.com/2013/05/small-business-marketing-guide-types-of-traditional-and-online-marketing/ Accessed: 2015-08-28.

17. Salehi, M., Mirzaei, H., Aghaei, M. \& Abyari, M. (2012). Dissimilarity of e-marketing vs traditional marketing, International journal of academic research in business and social sciences, January 2012, 2 (1), pp. 384-389.

18. Seriously simple marketing. (2015). Traditional vs. Online marketing: The real value of your online marketing efforts. Available at: http://seriouslysimplemarketing.com/traditional-vs-online-marketing/. Accessed: 2015-08-28.

19. Sledzik, C. (2014). Small businesses avoid social media and digital marketing because it's 'too complicated' and 'time consuming'. Available at: http://brandmuscle.com/blog/local-smb-avoid-social-media-and-digital-marketing/. Accessed: 2015-08-28.

20. Taherdoost, H. \& Jalaliyoon, N. (2014). Marketing vs E-marketing, International Journal of Academic research in management (IJARM), 3 (4), pp. 335-340. Available at: http://elvedit.com/journals/IJARM/wpcontent/uploads/2015/01/marketing-e-marketing.pdf. Downloaded: 2015-08-28.

21. Van Scheers, L. (2011). SMEs' marketing skills challenges in South Africa, African Journal of Business Management, 5 (13), pp. 5048-5056.

22. Walsh, M.F. \& Lipinski, J. (2009). The role of the marketing function in small and medium sized enterprises, Journal of small business enterprise development, 16 (4), pp. 569-585. Available at: http://dx.doi.org/10.1108/14626000911000929. Accessed: 2015-08-27. 